\title{
"Da ditadura à democracia", o difícil caminho para uma (re) democratização de Angola: Entrevista com Luaty Beirão
}

Por Aline Najara da Silva Gonçalves ${ }^{1}$

Angola, enquanto país independente, tem uma história muito recente. Sua emancipação política data de onze de novembro de mil novecentos e setenta e cinco, porém a independência colonial não significou um marco para a história de uma nação que rompia com as amarras do imperialismo. Com o avançar dos anos, o 11/11/1975 se tornou o início de uma trajetória de autoritarismos, repressão e privação de liberdades, inclusive a liberdade de pensar, tomada como ato criminoso passível de punição.

Rodrigo de Souza Pain, em A centralização política e autoritarismo em Angola, lembrou que "a situação da sociedade civil após a independência consolidou-se com características muito parecidas com o período português, principalmente naquilo que diz respeito ao autoritarismo, marcante naquele momento" ${ }^{2}$. Pain analisou o bloqueio do estado angolano no sentido de impedir “o futuro crescimento da sociedade civil em Angola". Além de alertar às barreiras para o desenvolvimento da sociedade civil angolana, neste artigo, Rodrigo Pain lembra que a configuração política de Angola se alicerça num espaço onde não há neutralidade, uma vez que sua instituição se deu de forma autoritária e traumática para a população, de modo que a sociedade mergulhou numa "cultura da violência e do medo". 3

A Constituição da República de Angola, de 2010, objetiva "edificar, em Angola, um Estado democrático de direito e uma sociedade justa”. Sua leitura mostra que aquele é um povo revestido "de uma cultura de tolerância e profundamente comprometidos com a reconciliação, a igualdade, a justiça e o desenvolvimento", estando a Carta Magna determinada a edificar uma "sociedade justa e de progresso que respeita a vida, a igualdade, a diversidade e a dignidade das pessoas" ${ }^{4}$. O Artigo $2^{\circ}$

1 Mestra em Estudo de Linguagens (UNEB), Especialista em História e Cultura Afro-brasileira (FAVIC) e Licenciada em História (UNEB). Atualmente é docente da disciplina História e Cultura Afro-brasileira e Indígena na Faculdade Regional da Bahia (FARAL - UNIRB). E-mail: alinasigo@gmail.com .

2 PAIN, Rodrigo de Souza. A centralização política e autoritarismo em Angola. In: Histórica - Revista Eletrônica do Arquivo Público do Estado de São Paulo, n.33, 2008, p. 4. Disponível no site $<$ http://www.historica.arquivoestado.sp.gov.br/materias/anteriores/edica033/materia06/texto06.pdf $>$. Acesso em 25 de março de 2016.

3 Idem, p.5.

4 Cf. Constituição da República de Angola. Disponível no site $<$ http://www.governo.gov.ao/Arquivos/Constituicao_da_Republica_de_Angola.pdf $>$. Acesso em 27 de março de 2016 , às $21 \mathrm{~h}$. 
- Do Estado Democrático de Direito, determina:

\begin{abstract}
A República de Angola é um Estado Democrático de Direito que tem como fundamentos a soberania popular, o primado da Constituição e da lei, a separação de poderes e interdependência de funções, a unidade nacional, o pluralismo de expressão e de organização política e a democracia representativa e participativa. 2. A República de Angola promove e defende os direitos e liberdades fundamentais do Homem, quer como indivíduo quer como membro de grupos sociais organizados, e assegura o respeito e a garantia da sua efectivação pelos poderes legislativo, executivo e judicial, seus órgãos e instituições, bem como por todas as pessoas singulares e colectivas. (Grifos nossos)
\end{abstract}

Embora a Constituição assinale a existência de uma democracia em Angola, onde o pluralismo político e participação em de grupos sociais organizados são um direito garantido, na prática, o que se vê, são privações, controle excessivo, autoritarismos e a vigência de um regime ditador que desvirtua e ressignifica naquele contexto o que deveria ser uma democracia.

A conversa transcrita a seguir é fruto de uma inquietação frente à realidade de desmandos do governo do Sr. José Eduardo dos Santos - o "Zedu”, que preside Angola desde 1979 —, em relação à prisão e julgamento dos ativistas de direitos humanos do "Movimento Revolucionário", nomenclatura esta que, segundo Luaty Beirão, "foi mais uma fabricação da mídia do que qualquer outra coisa".

Os "15+2", como são chamados nas campanhas em prol da libertação nas redes sociais, foram presos em 20 de junho de 2015, enquanto se reuniam para a leitura do livro Ferramentas para destruir o ditador e evitar nova ditadura - Filosofia politica da libertação para Angola, escrito pelo jornalista Domingos Cruz (Mestre em Direitos Humanos pela Universidade Federal da Paraíba) e inspirado na obra Da Ditadura à Democracia: Uma estrutura conceitual para a libertação, de Gene Sharp. Acusados pelas forças de segurança angolana, de organizarem atos que punham em risco a ordem e a segurança pública do país, naquele momento, Henrique Luaty da Silva Beirão, Manuel Chivonde (Nito Alves), Nuno Álvaro Dala, Afonso Mahenda Matias (Mbanza Hanza), Nelson Dibango Mendes dos Santos, Itler Jessy Chivonde (Itler Samussuko), Albano Evaristo Bingocabingo, Sedrick Domingos de Carvalho, Fernando António Tomás (Nicolas, “o Radical"), Arante Kivuvu Italiano Lopes, Benedito Jeremias, José Gomes Hata (Cheick Hata), Inocêncio António de Brito, Domingos da Cruz, Osvaldo Sérgio Correia Caholo, Laurinda Gouveia e Rosa Conde, iniciavam um longo caminho que foi da prisão fechada e isolamento familiar, à prisão domiciliar e, posterior condenação por atos de preparatórios de rebelião e associação de malfeitores, num julgamento controverso, resultando em penas que variaram de dois a oito anos de prisão efetiva em regime fechado, em 28 de março deste ano.

Luaty Beirão, rapper luso-angolano, conhecido como Ikonoklasta, é visto por muitos como o 
líder do movimento, embora deixe claro que não há ali lideranças ou rótulos, mas jovens que propõe uma Angola livre e democrática. Esta "conversa" foi finalizada dia 26 de março de 2016 — às vésperas do julgamento que resultaria em sua condenação - enquanto encontrava-se em prisão domiciliar, e só foi possível pelo empenho do ativista João António Zanzuca (NorbertoNor), que intermediou o contato com o Luaty Beirão. ${ }^{5}$

Luaty Beirão, é um prazer realizar esta conversa contigo e tentar trazer ao Brasil um olhar sobre a realidade da política de governo angolana. Gostaria que falasse sobre o Movimento Revolucionário em Angola. Como esse movimento foi criado? Esse nome foi dado por vocês ou é uma criação da mídia? Existe um meio de divulgação das propostas do grupo? O que exatamente vocês buscam nesse movimento de ativistas de uma juventude angolana? Como é esta atuação de vocês enquanto ativistas que combatem esse sistema, que apesar de se dizer democrático, mostrase ditador?

É uma da manhã aqui em Luanda. Eu não sei se será possível acabar essa conversa toda hoje, mas vou tentar avançar o máximo possível até porque eu não sei exatamente o que é que vai acontecer na segunda feira, quando já tenho a última sessão do julgamento; a leitura do acordo. Como estou a mentalizar-me para um regresso à prisão, vou ter que despachar isto. [...] É bem estranha essa forma de conversa [risos]. Não é assim tão orgânico como deveria ser, não é? [risos]

Bem, sobre o Movimento Revolucionário, foi mais uma fabricação da mídia do que qualquer outra coisa. Na verdade, desde 2011, quando fomos nos conhecendo uns aos outros e descobrimos que tínhamos pontos em comum, não existia movimento algum. Não existia nenhum agrupamento. A maior parte das pessoas nem sequer se conhecia. O que aconteceu foi que no fim de 2010 começou a haver uma onda de contestação no norte da África. Começou na Tunísia, onde um cidadão chamado Mohamed Bouazizi em protesto contra o desemprego e a corrupção das autoridades locais, ateou fogo em seu próprio corpo. Aquilo foi inspirador para as pessoas que vivem em regimes totalitários, inclusive para nós aqui. Muitos perfis anônimos surgiram e começou a haver uma crescente tentação a seguir no mesmo rumo e apareceu alguém que marcou uma data para as pessoas irem à rua e pedir a queda do regime. Primeiro eu não estava incitado a aderir a isso porque não gosto de coisas convocadas de forma anônima, sobretudo no contexto em que nós vivemos, mas houve um somatório de coincidências porque, sendo músico também, tive um convite

5 O contato com Luaty Beirão foi realizado através da troca de emails e mensagens via whatsapp. Como Luaty encontrava-se em prisão domiciliar, as perguntas foram enviadas para o Sr. João António Zanzuca, que intermediou o contato e encaminhou as respostas para o meu email em arquivos de áudio gravados pelo Luaty e transcritos nestas linhas. 
para cantar uma semana antes da data do protesto. Tive um mês a ensaiar e na verdade não estava a ligar muito àquele apelo. $\mathrm{O}$ que me chamou a atenção foi ver que estava a ganhar amplitude e foi, sobretudo, a forma que o regime reagiu publicamente; a preocupação que mostrou e a linguagem que utilizou para tentar desmobilizar as pessoas. Isso surtiu efeito contrário. Quando subi ao palco naquele dia, foi para fazer uma declaração de que estaria presente, independentemente de quem tivesse convocado... Estaria presente nesta manifestação e que esperava convocar toda aquela plateia de dois mil e tal, três mil pessoas, que eram ouvintes de rap consciente, portanto, rap com mensagem, que fala de problemas sociais e políticos... Era a plateia adequada para recrutar pessoas. Mas eu não fui organizador. Se calhar fui umas das primeiras pessoas a publicamente assumir que lá estaria; a desafiar o sistema. Bem, isso depois de uma centena de anônimos na internet. Isso causou alguma comoção e com os efeitos midiáticos de repente eu comecei a sentir a pressão e as consequências do meu ato e as coisas encadearam-se. Logo ali no fim do conserto algumas pessoas que já conhecia do Hip hop e dos eventos de Rap, aproximaram-se e manifestaram interesse em estar também. Chamar isso de movimento, se calhar é banalizar um pouco uma palavra que requer algo de alguma amplitude. Então fomos lá no sete de março. Éramos cerca de treze pessoas e quatro jornalistas... fomos 17 pessoas detidas nessa noite. A repressão em vez de parar nos deu vontade de desafiar esta estrutura. Fomos ler as leis e descobrir como se convoca uma manifestação e a forma legal e convocamos uma manifestação. A coisa foi se chamando assim "movimento", porque queríamos que fosse algo que atingisse proporções nacionais, mas pelo menos na minha filosofia, nunca houve a intenção de criar algo firmal, estruturado. Para mim o conceito de movimento é algo que nos escapa e é maior que nós. Qualquer pessoa que esteja disposta a desafiar o medo e esta teia pervertida de corrupção e maldade... esses atos de rebeldia isolados, para mim são a tal coisa que se concebe como movimento. Ao longo dos nossos debates este era um tema permanente, inclusive no momento em que fomos presos este era um tema que estava em cima da mesa: as vantagens e desvantagens de se ter um nome, de estar organizado, se havia necessidade dessa coisa mais estruturada. Essa é uma discussão que não canso de ter, mas defendo que a coisa deve ser assim sem nome, sem a preocupação de reivindicar o seu lugar e seu espaço na História. A imprensa e toda gente à sua volta é que tem a necessidade de nos rotular e por uma etiqueta, pôr no sítio certo na loja de livros... Os jornalistas foram tentando vários nomes: Movimento Estudantil, movimento Universitário, Movimento Intelectual, Movimento Revolucionário. E alguns dos jovens com quem a gente organizava essas manifestações, gostava de se ver como Movimento Revolucionário, de serem definidos como tal. Em 2013 houve uma fratura, que poderia ser saudável, mas não foi... 
desejávamos que este grupo não fosse antagônico. Este fragmento adotou o nome de movimento revolucionário angolano e tem estatutos, simpósios... uma coisa muito oficial. A verdade é que a coisa minava o rumo das coisas que estávamos interessados em atingir do que ajudar propriamente. Não foi uma fase boa para os ativistas em Angola. Basicamente foi isso... foi assim que foi aparecendo a coisa e não é de todo linear. O foco é mostrar onde está o problema, que é o Presidente da República, que não apresenta nada de novo, é desalentador. Foi preciso identificar o problema, mas esse problema não gosta de ser apontado. O foco é esse! As eleições não são justas, transparentes nem livres. O processo é sempre manipulado, com fraudes, inclusive. Assim, o entendemos como um ditador, que não se preocupa com o bem estar do coletivo. Portanto, nosso foco é exigir o que consta na Constituição e cobrá-los de uma forma que desagrada, irrita. Pedimos que haja uma mudança no sistema e o objetivo é fortificar a sociedade civil e despartidarizar as mentes. Fazer com que cada cidadão sinta que tem direitos e que deve fiscalizar o Estado.

Agora queria que falasse um pouco da sua trajetória anterior a esse movimento. Pesquisando acerca da sua biografia, pude perceber que seu pai tinha uma filiação ao MPLA antes do José Eduardo dos Santos, desde o período do Agostinho Neto. Vi que ele foi diretor da Fundação José Eduardo dos Santos, inclusive. Então, como era sua relação desde esse momento, dentro da sua família, com o MPLA? Houve uma mudança no partido após essa troca; após a morte do Agostinho Neto, quando começa essa ditadura do José Eduardo dos Santos? Como se processou essa mudança dentro do próprio partido, que lança as bases para as contestações do movimento que vocês realizam? Como você se coloca dentro desse contexto, como alguém que cresceu próximo às fileiras do MPLA e que hoje é um dos representantes mais fortes da oposição?

Sou jovem, nasci em Luanda, em 1981, sou filho de pais angolanos, pai e mãe. Meu pai do Huambo, minha mãe de Luanda. Cresci no contexto de um país em guerra, com partido único. País dividido... quem ficou por cá forçosamente fazia parte do partido e meu pai não era diferente. Ele acreditava nos ideais iniciais do partido, mas ele não falava comigo acerca de política. Em casa não havia qualquer símbolo que fosse do partido e ele nunca me obrigou a fazer parte desse mundo. E não foi depois de Agostinho Neto. Ele próprio criou os problemas que previu. Não houve uma grande mudança... o Agostinho Neto também geriu muito mal. Poderia até ter boas intenções, mas não descascou bem o pepino que tinha em mãos. O 27 de maio foi possivelmente o episódio mais traumático do pós-colonialismo em Angola, sobretudo porque foi uma depuração entro do próprio 
partido e para sobreviver as pessoas começaram a ser camaleões ${ }^{6}$. Aquilo repercutiu e os pais passavam medo aos filhos... os filhos tinham medo sem saber de quê. A guerra civil durou 27 anos e cresci numa fase bem conturbada, mas meu pai não me doutrinou e me deixou ser eu. Não tentava amenizar quando me via chateado com a condição no país, apenas me pedia paciência e que compreendesse os problemas numa complexidade. Tive um pai libertário neste sentido. Nos últimos anos de vida tivemos pequenos conflitos, mas nada que pudesse afetar nossa relação pai e filho. Como disse, o José Eduardo não é culpado por todas as mudanças no MPLA, mas como está no poder há muito mais tempo, é muito mais documentada a sua mudança de rumo, sobretudo após a queda do muro de Berlim e o fim da Guerra Fria, quando percebeu que seria necessário fazer uma falsa abertura a um ambiente multipartidário e democrático e rapidamente descobriu como tirar proveito disso e hoje estamos a colher os frutos do que ele assumiu. Muita tensão... muita tensão... [sussurros].

Agora vou levantar uma questão mais próxima desse momento que você está vivendo. Você foi preso em junho do ano passado com outros dezesseis ativistas, acusados de estarem premeditando um golpe contra o Estado angolano por estarem lendo o livro "Ferramentas para destruir o ditador e evitar nova ditadura - Filosofia política da libertação para Angola”. Queria que você falasse um pouco a respeito desse momento da prisão e de como se desenrolou esse processo aí, inclusive um processo que é tido por muitos como inconstitucional, tendo em vista que fere com o que está previsto na Constituição Angolana. Houve uma repercussão muito grande, inclusive da imprensa externa a Angola e da Anistia Internacional de Portugal, principalmente por conta do período em que você esteve em greve de fome, e houve também certa divisão de opiniões nas redes sociais, onde alguns te veem como um grande líder e representante do movimento pela redemocratização em Angola, enquanto outros julgam vocês como desordeiros, rebeldes e agitadores. Fale um pouco de como se desenrolou este período do cárcere e como está sendo a prisão domiciliar, a que vocês ainda estão submetidos.

6 Aqui Luaty refere-se ao chamado "Fraccionismo", movimento de contestação ao MPLA, que desencadeou uma onda de prisões, torturas e assassinatos, apoiados pelo então presidente angolano, Agostinho Neto, em oposição a Nito Alves. Para maiores informações a respeito das tensões provocadas pelo 27 de maio na história angolana, ver MARQUES, Inácio Luiz Guimarães. MEMÓRIAS DE UM GOLPE: o 27 de maio de 1977 em Angola. Dissertação. Niterói, $2012 . \quad$ Disponível no site $<$ http://www.historia.uff.br/nec/sites/default/files/Marques_Inacio._Memorias de_um_golpe_o_27_de maio_de 1977 em_Angola.pdf $>$ Acesso em 25 de março. É possível também ter um painel bem mais amplo acerca do 27 de maio em Angola no site $<$ http://www.dw.com/pt/27-de-maio-de-1977-e-nito-alves-o-tabu-da-hist\%C3\%B3riade-angola/a-15925292> que traz uma série de reportagens, artigos e entrevistas sob o título 27 de maio de 1977 e Nito Alves - O tabu da história de Angola. 
Nós somos pessoas sob observação da polícia secreta e de todas as forças repressivas, porque assumimos publicamente o que pensamos e para eles somos gente perigosa e que deve ser espionada a todo tempo por isso. Era a sexta sessão em que estávamos a ler o livro e a debater como ele se aplicaria em Angola, como é possível, como não é, como se mobiliza as pessoas e se explica o que é desobediência civil... Enfim, explicar como se reivindica os direitos e leis, e convencê-las a entender as formas de resistência pacificas prevista e omissas da Constituição. Íamos na discussão quando de repente irrompe ali um efetivo de cerca de 15 agentes com arma em punho e alguns filmando a ação, numa sala que nem chegava a $15 \mathrm{~m}^{2}$. Sinceramente cheguei a pensar que seríamos fuzilados, mas depois, em questão de segundos, vi que seríamos mesmo era presos. Lá fora haviam mais de trinta pessoas e havia praticamente um carro para cada um e muitas polícias, com coletes, máscaras e um aparato que parecia filme. Fomos levados - os treze que ali estavam e os outros foram presos depois - , nossas casas foram invadidas e queríamos saber porque estávamos ali. Foram às nossas casas arbitrariamente e entraram a força. A experiência da prisão não foi necessariamente traumática. Nos primeiros 90 dias ficamos isolados e chegamos a ficar por 47 horas sem ver a luz do dia. Foi uma pressão psicológica muito forte e alguns ficaram com problemas de saúde, mas eu pensei que seria ainda pior. Na prisão que estive fiquei alguns dias com a população prisional e depois me puseram num sítio menos mal. Pude aproveitar pra ler muito e pensar na continuidade do que eu quero da vida. Logicamente que não queria passar pela experiência de ser preso, mas aproveitei enquanto estava preso e consegui ver coisas positivas da experiência. Ler foi uma das coisas que fiz. Li muito. A divisão de opiniões é natural em uma sociedade polarizada como a nossa, aonde as pessoas estão completamente contra, ou estão em cima do muro, e depois de outro lado, aqueles que estão comendo do sistema e estas são as que nos combatem ferozmente e existem pessoas de todo tipo e manipulam a justiça e são os "todopoderosos". Nós somos só os "miudinhos" [risos], somos pessoas com a fragilidade dos nossos corpos, como diria o Nelson Bonavena, e nos oferecemos à sua brutalidade em defesa de um princípio maior, um princípio liberdade, um princípio de igualdade, um princípio de justiça social, que até parecem clichês, mas é o que é na verdade. A prisão domiciliar tem sido uma experiência mais relaxada. Contrariamente à maior parte dos meus companheiros, eu tenho uma casa grande, com piso térreo e primeiro piso, um pequeno quintal à frente e um espaço pra apanhar sol. Sou de uma família de classe média alta, portanto não tenho grandes carências, mas sobretudo o fato de poder reencontrar-me com a minha pequena Luena, de dois anos, foi o mais importante, me deixando perceber quanta falta ela me fez. Mas eu acho que há coisas mais importante do q o nosso 
bem estar individual. O que vivemos aqui não é uma solução. O egoísmo cresceu de forma absolutamente alucinante e o que se vê na maneira como os ricos se protegem, como é falsa a noção de segurança que a gente tem, isso não é saudável. Portanto eu acho q é importante pra minha filha viver num ambiente mais saudável, portanto não vou evitar voltar pra prisão, sobretudo porque o que eu faço não é ilegal, é pregar uma vida melhor para todos baseado na Constituição da República do meu pais. Deixar de fazer essas coisas seria dar a vitória e ceder para a tirania, a prepotência e arbitrariedade, e onde reina a arbitrariedade a gente nunca tem certeza de vir a ver o dia seguinte. Nós queremos mudar isso! Nós queremos que haja responsabilização, que o colarinho branco também seja preso. Estou a lidar bem com a prisão domiciliar, mas não é liberdade. E liberdade é o que a gente quer.

Na sua trajetória como rapper, como o Ikonoklasta, vejo que há muito esse tom de discussão de questões sociais e denúncia em relação a esta questão política e todas essas proibições que vocês vivem no contexto da realidade angolana. O papel da música e do Rap em específico, dentro dessa proposta de contestação da ordem imposta sempre foi uma ferramenta muito forte no que diz respeito ao posicionamento político, principalmente da juventude. Vi, principalmente através do site da Central Angola, que vocês se posicionam sobre a ação de outros rappers também que são convidados a fazer shows em Angola. Ano passado foi direcionada uma carta a Nic Minaj e esse ano a Gabriel, o Pensador, que é um rapper brasileiro. Na carta resposta, o Gabriel, $O$ Pensador disse que desconhece a realidade do ativismo em Angola e desconhece quem são os presos. Como você analisa esse posicionamento $e$ a importância do rap nesse contexto de luta por uma sociedade politicamente mais viável? Para você, qual seria o papel do rapper como artista político?

Minha trajetória como rapper não foi sempre focada em trajetórias políticas. Estou longe de ser um rapper como o Gog ou os Racionais. Comecei muito cedo. Eu tinha treze anos e, obviamente, estas questões não me diziam muita coisa. Mas amadureci e minha música também amadureceu, portanto à medida que fui ganhando consciência social e política, minha música foi conhecendo isso, mas tem muita coisa que não é necessariamente social ou política. Quanto a Nicki Minaj e o Gabriel, o apelo a essas figuras é obvio porque eles têm grande alcance mundial e faria chamar atenção acerca do assunto e ajudaria aqueles que lutam por um ideal de democracia. Mas a Nicki Minaj não era exatamente a pessoa certa, porque nunca a vi ligada a questões sociais de quaisquer países. Eu não estava a espera que funcionasse, por isso não fiquei surpreendido. Já com 
o Gabriel, a história é um bocado diferente. Não quero entrar muito por aí porque já deu pano pra manga, mas achei até que foi de alguma forma nobre ele tentar responder e mostrar que deu importância suficiente pra tentar esboçar uma reposta. Quanto a ser satisfatória, obviamente que não é. Não esperava que boicotasse, mas achava que faria alguma referência em palco sem necessariamente boicotar um espetáculo que já tinha um contrato... Havia várias formas de fazer cá qualquer coisa, por mais simbólica que fosse, tendo em conta o background do Gabriel. [pausa] Mas acho é que o Rap e o Hip Hop sempre foi para mim uma forma de despertar consciência. Sempre foi algo muito positivo que me fez pensar e ajudou muito os meus posicionamentos ao longo da vida. Costumo dizer que, antes de minha filha nascer, foi o maior acidente, o melhor e o mais bonito que já tive em minha vida, foi descobrir isso ou fazer eu descobrir isso, essa cultura magnífica; essa forma de expressão fantástica que é o Hip Hop e o Rap. Aqui em Angola não é diferente. Durante muitos anos o Rap foi praticamente a única forma de intervenção digna desse nome, ou pelo menos, consistente, que não foram atos isolados... era consequente e contínuo. Sobretudo após 1999, a coisa começou a ficar mais interessante. Fui muito inspirado pelos Filhos da Ala Este e pelo meu mano MC Kapa. Eles tiveram um lugar especial na história do Hip Hop consciente, positivo, político e de impacto que tiveram em mim, pessoalmente. O Rap hoje, apesar de estar mais cooptado, regimentado... os rappers que conseguiram ganhar algum impacto não são muito vocais. Alguns fogem com o rabo à seringa e são mais das indiretas. Seria este um bom momento para tomarem uma posição e não serem ambíguos. Ainda assim o Rap continua a ser das formas de arte mais diretas e mais frontais de intervenção neste país e neste contexto.

Outra questão, diz respeito à repercussão do caso. Como você analisa as campanhas realizadas pela Anistia Internacional Portugal pela libertação de vocês, levando em conta que este caso teve um alcance mundial e deixou de ser um problema exclusivo de Angola para ser uma questão de reflexão sobre a manutenção de uma democracia; dos direitos do cidadão dentro de um processo verdadeiramente democrático...

Essa repercussão mundial tem algo a ver com o fato de ter um histórico artístico, né. Eu acho que essa repercussão começou timidamente e ganhou muito maior expressão depois da Ana Gomes ter cá vindo da primeira vez e ter havido uma censura do parlamento europeu e depois com a greve de fome. Parece que aí foi exponencial o aumento da tensão. Sempre houve algum posicionamento de organizações internacionais, mas no meio das causas que defendem, me parece que não era uma que tivesse protagonismo às vezes as portas não se abrem e as pessoas não estão 
tão incomodadas com aquilo. É preciso ter uma certa cacofonia... aí houve uma escalada. Obviamente estou muito satisfeito com a repercussão que teve, logicamente. Foi bom quando houve esse pico. Nos sentimos mais protegidos.

Queria que falasse um pouco sobre as suas expectativas para o desencadear do julgamento. Como está sendo a preparação com a família e o que você espera para os próximos dias? Quais os direcionamentos que pretendem dar?

Eu só vou prever até segunda-feira, que é o dia da leitura sentença. Depois disso não quero pensar muito, sobretudo porque estou a tentar preparar-me psicologicamente para o absurdo e o absurdo será a condenação. E o absurdo ao cubo é a condenação com condução imediata para a comarca. Nossa lei prevê que, independentemente do acordo que vem ser pronunciado pelo juiz, os advogados podem interpor recurso imediato e isso que vão fazer. Ao interpor recurso, a pena pode ficar com efeito suspensivo, mas nossa realidade é outra e não se coaduna com nenhum quadro legal, nem mesmo o nosso, então será a vontade dessas pessoas... Portanto, estou a me preparar para o pior quadro punitivo possível, que parece-me ser doze anos de condenação. Esta é minha forma de não me sentir desapontado ou desiludido, pois sem bem como as coisas acontecem aqui. Basicamente, estou a conversar com a família para estarem preparados para meu não regresso na segunda-feira.

Luaty Beirão foi condenado a cinco anos e seis meses de prisão, na segunda-feira que seguiu a esta conversa, em 28 de março de 2016, acusado também de falsificação de documentos. As penas aos demais integrantes do grupo, variaram de dois a oito anos, todos em regime fechado. Luaty fora levado à Cadeia de Viana, mas atualmente encontra-se no Hospital-prisão de São Paulo. Está com a saúde debilitada pela malária e paludismo. Encerro este texto com palavras suas que refletem o desejo de todos aqueles que lutam pelo justo e pelo bem comum: "Deixar de fazer essas coisas seria dar a vitória e ceder para a tirania, a prepotência e arbitrariedade. $E$ onde reina a arbitrariedade a gente nunca tem certeza de vir a 
ver o dia seguinte..."7

7 Luaty Beirão, Mbanza Hanza, Domingos da Cruz e demais companheiros e companheiras, com exceção de Nito Alves - pois sua pena adicional de seis meses não está incluída nesta decisão — foram colocados em liberdade após pedido de habeas corpus da defesa, que alegou inconstitucionalidade no processo e pediu a absolvição dos envolvidos, na quarta-feira, 29 de junho de 2016. Apesar de celebrada, esta libertação é considerada provisória e não é sinônimo de liberdade, tampouco de vitória da democracia e dos direitos humanos. Segundo o site da Conectas (uma organização não governamental internacional e sem fins lucrativos, fundada em setembro de 2001, em São Paulo), por determinação da justiça, Luaty Beirão e demais ativistas estão proibidos de sair do país e deverão se apresentar mensalmente às autoridades, além de serem obrigados a comparecer ao tribunal sempre que solicitados. Cf. Angola: A luta por justiça continua. Disponível no site http://www.conectas.org/pt/acoes/sur/noticia/45763-angola-a-luta-por-justica-continua Acesso em 18 de julho de 2016 , às $23 \mathrm{~h} 38 \mathrm{~min}$. 